\title{
Dziedzictwo kulturowe wsi Pokój (dawne Carlsruhe) w województwie opolskim. Zanikanie, ochrona, promocja
}

Zarys treści: Wieś gminna Pokój położona jest w północnej części województwa opolskiego. W XVIII wieku książę wirtembersko-oleśnicki Karl Christian Erdmann wniósł tu założenie rezydencjalne $\mathrm{w}$ formie gwiaździstej kompozycji z centralnym placem, ogrodami i parkami. Miejscowość o nazwie Carlsruhe stała się ośrodkiem kultury i rzemiosła, a od XIX wieku uznanym uzdrowiskiem. Zniszczenia wojenne dokonane w 1945 roku przerwały rozwój miejscowości, a dawne Carlsruhe stało się wsią Pokój. W rozdziale przedstawiono współcześnie realizowane działania i projekty w kierunku ochrony i promocji zachowanego dziedzictwa Pokoju, na tle historii miejscowości i jej kulturowej specyfiki. Opracowanie wskazuje, że po okresie powojennej stagnacji i degradacji, XXI wiek przyniósł szereg nowych możliwości i narzędzi sprzyjających ochronie wyjątkowego dziedzictwa wsi Pokój i przywróceniu jego dawnych wartości, jak również zrównoważonemu wykorzystaniu tego dziedzictwa dla rozwoju miejscowości, gminy i regionu.

Słowa kluczowe: dziedzictwo kulturowe, działania w obszarze ochrony i promocji, województwo opolskie, Pokój, Carlsruhe.

\section{Wprowadzenie \\ Pokój do 1945 roku - zarys historii i charakterystyka}

Położona w północnej części województwa opolskiego i otoczona kompleksem lasów wieś gminna Pokój to dawne Carlsruhe, miejscowość o szczególnej historii. W XVIII wieku Karl Christian Erdmann¹, książę wirtembersko-oleśnicki, wzniósł

\footnotetext{
${ }^{1}$ Karl Christian Erdmann (1716-1792), książę wirtembersko-oleśnicki, urodził się w Brzozowcu k. Namysłowa. Właściciel księstwa oleśnickiego, założyciel położonego w Borach Stobrawskich Carlsruhe. Wśród kolejnych właścicieli Pokoju wspomnieć warto księcia Eugena (III) Erdmanna, uczestniczącego w wojnie prusko-francuskiej w stopniu generała dywizji, interesującego się astronomią i poezją, który dzięki zaletom charakteru zyskał wśród mieszkańców miejscowości przydomek „Dobry” oraz księcia Nikolausa, który na przełomie XIX i XX wieku ożywił gospodarkę miejscowości w zakresie rolnictwa i leśnictwa. Na początku XX wieku Carlsruhe stało się siedzibą królewską. Ostatnim tytularnym właścicielem Pokoju jest książę Ferdinand, mieszkający na stałe w Niemczech (Schmidt 1998: 39-41).
} 
tutaj założenie rezydencjalne $\mathrm{w}$ formie promienisto-koncentrycznego układu z ogrodami, parkami i zwierzyńcem ${ }^{2}$ (ryc. 1). Geometryczny środek kompozycji stanowił okrągły plac, z którego wychodziło osiem promienistych alei. Na centralnym placu usytuowano pałac w otoczeniu dworskich oficyn (ryc. 2). Na jednej z alei wzniesiono kościół ewangelicki z towarzyszącym cmentarzem. Wśród zakładanych z dużym rozmachem założeń parkowych i ogrodowych wyróżniał się ogród w stylu francuskim, usytuowany w pobliżu pałacu oraz rozciągające się w kierunku południowym rozległe założenie parkowe w stylu angielskim (ryc. 3). Park urozmaicały stawy, kanały, wzgórza oraz elementy parkowej architektury i rzeźby (świątynie, sztuczne ruiny, posągi, pomniki).

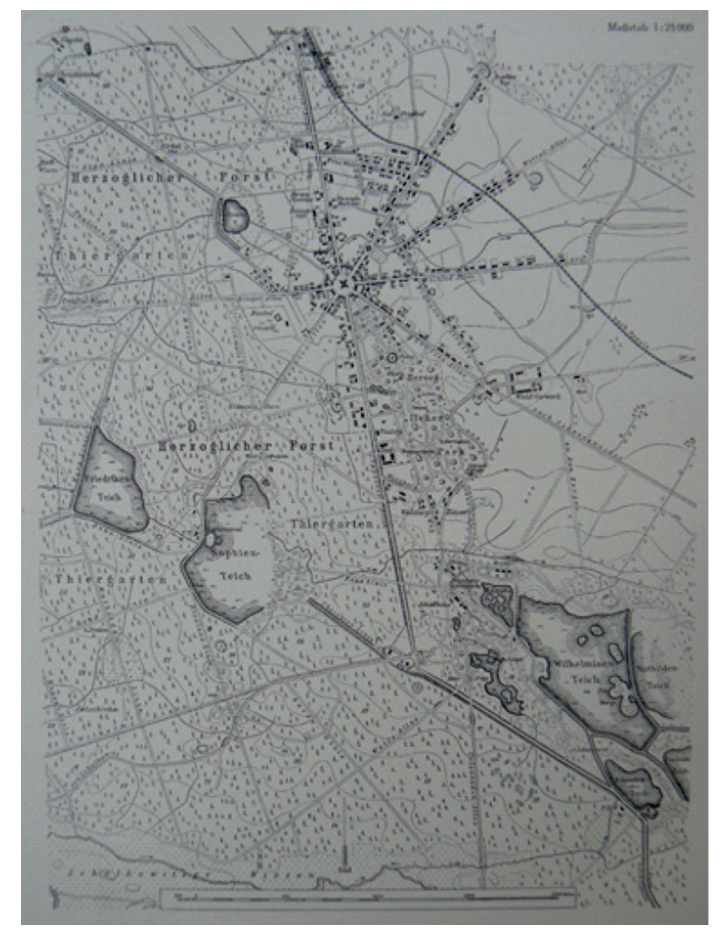

Ryc. 1. Promienisto-koncentryczny układ urbanistyczny Carlsruhe $\mathrm{z}$ centralnym placem

Źródło: R. Konwiarz (1919: 220)

${ }^{2}$ Główną siedzibą książąt oleśnicko-wirtemberskich była Oleśnica. Książę Karl Christian Erdmann początkowo planował założenie w Pokoju jedynie zwierzyńca na planie ośmioramiennej gwiazdy (tzw. Gwiazdy Myśliwskiej - niem. Jagdstern). Układ miał zawierać centralny plac z pałacykiem myśliwskim oraz gwiaździste układy dróg leśnych. Projekt został zrealizowany częściowo. Zniszczony pożarem drewniany pałacyk myśliwski zastąpiono murowaną budowlą o funkcji letniej rezydencji książęcej, a Carlsruhe rozbudowano jako rezydencjalne założenie urbanistyczne (Gosławska, Schmidt 2015: 15-26). 


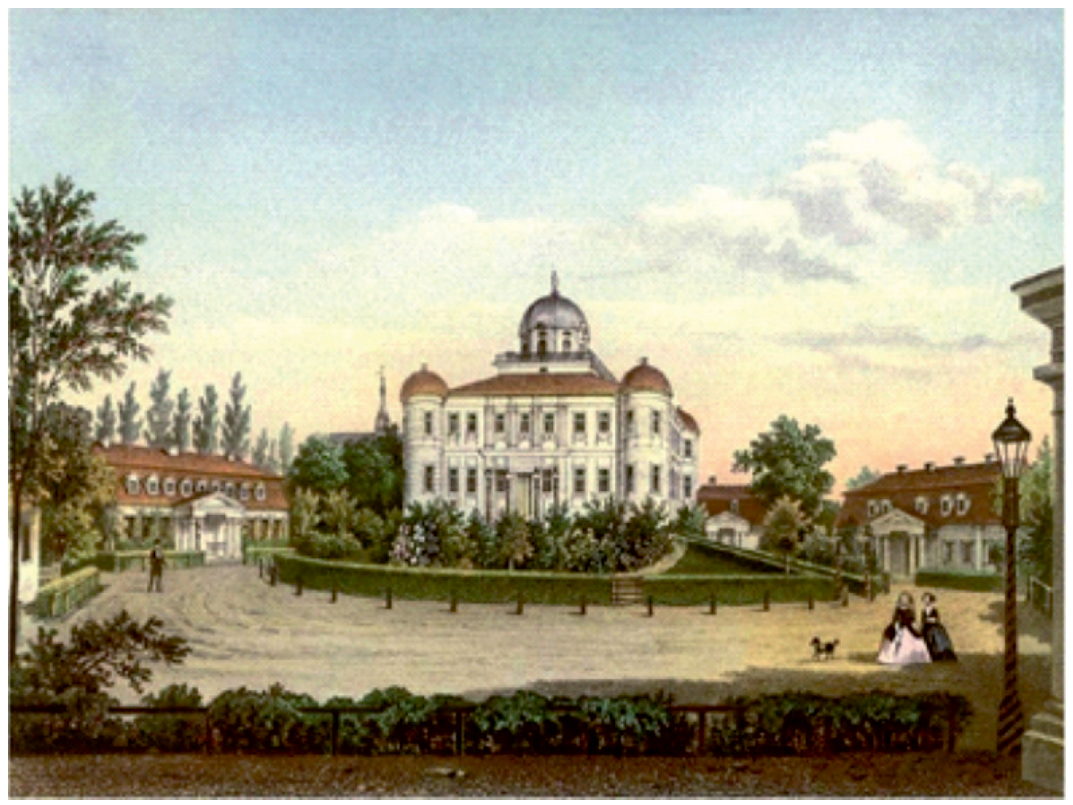

Ryc. 2. Pałac książąt wirtembersko-oleśnickich na centralnym placu, w otoczeniu dworskich oficyn. XIX-wieczna litografia A. Dunckera Źródło: Wojewódzka Biblioteka Publiczna w Opolu

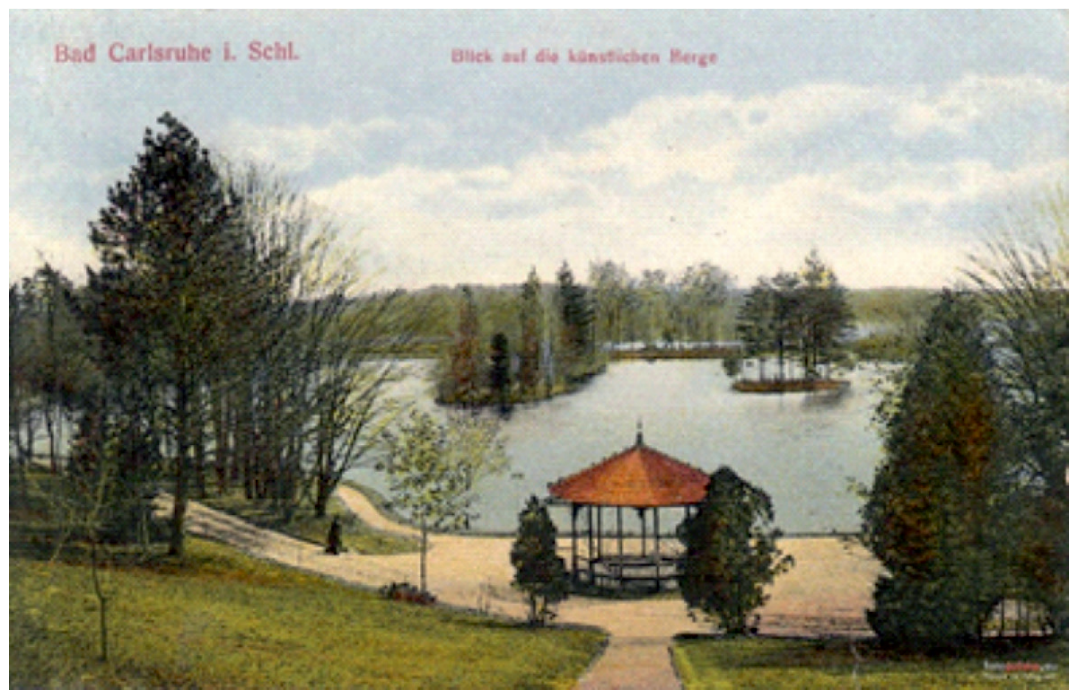

Ryc. 3. Staw Heleny w dużym parku angielskim w drugiej dekadzie XX wieku Źródło: https://fotopolska.eu/646544,foto.html?o=b97187 (dostęp: 20.06.2020) 
Twórcą założenia i części głównych obiektów był książęcy architekt i budowniczy Georg Ludwig Schirmeister ${ }^{3}$. W Pokoju, na zlecenie księcia, działał również Carl Johann Leyser - autor m.in. klasycystycznej świątyni Matyldy w parku angielskim oraz tzw. zamku letniego (później domu koncertowego) ${ }^{4}$. Geometryczny ogród francuski składający się z czterech części i wyposażony w liczne atrakcje zrealizował ogrodnik Websky w oparciu o założenia projektowe Schirmeistera. Projekt rozległego parku angielskiego opracował C.J.G. Klöber, związany przez większość swojego życia zawodowego z Pokojem 5 .

Geometryczne rozplanowanie całości, z centralnym usytuowaniem książęcej rezydencji, wykazuje wpływy francuskie (Wróbel 1971), przypomina również promienisto-koncentryczny układ XVIII-wiecznego miasta rezydencjalnego Karlsruhe w Badenii-Wirtembergii.

Miejscowość, dzięki książęcemu mecenatowi, stała się ośrodkiem kultury teatralnej i muzycznej. Już w XVIII wieku jedną z dworskich oficyn zaadaptowano na teatr, angażowano zawodowych aktorów. W repertuarze znalazły się komedie, tragedie i opery, a wśród nich spektakl „Czarodziejski flet” z możliwością bezpłatnego wstępu (Schmidt 1998). Istotną częścią życia kulturalnego miejscowości były również wydarzenia muzyczne, funkcjonowała orkiestra oraz chór. Na początku XIX wieku na dworze książęcym przebywał wybitny kompozytor niemiecki Carl Maria von Weber ${ }^{6}$. Podczas pobytu w Pokoju powstały niektóre z jego dzieł. Do dalszego rozkwitu życia muzycznego przyczynił się uzdolniony muzycznie książę Eugen (II) Erdmann, właściciel Pokoju w latach 1822-1857. Publiczne koncerty odbywające się cyklicznie w tym okresie przyciągały wielu miłośników muzyki (Schmidt 1998).

${ }^{3}$ Georg Ludwig Schirmeister (1716-1784), urodzony w Brandenburgii radca budowlany oraz architekt w służbie księcia wirtembersko-oleśnickiego. Działalność projektowa na terenie księstwa oleśnickiego (Bierutów i Oleśnica, również wsie) oraz dóbr książęcych w Pokoju. Twórczość G.L. Schirmeistera wpisuje się stylistycznie w okres pomiędzy późnym barokiem a wczesnym klasycyzmem (Bimler 1930: 30-34; Nienałtowski 2019: 171-175).

${ }^{4}$ Carl Johann Leyser (1754-1823), urodzony w Dreźnie (Saksonia), radca wojenny i budowlany we Wrocławiu (Schmidt 1998: 11-16, 42-43).

${ }^{5}$ C.J.G. Klöber (1759-1821), urodzony w okolicach Oleśnicy, od 1772 r. w służbie książąt wirtembersko-oleśnickich, od 1792 r. praca zawodowa wyłącznie w Pokoju, z inicjatywy księcia pogłębiał wiedzę ogrodniczą podczas wyjazdów studialnych m.in. do Lipska (Ibidem: 12, 43).

${ }^{6}$ Carl Maria von Weber (1786-1826), wybitny niemiecki kompozytor epoki romantyzmu, pianista i dyrygent. W dorobku kompozytorskim ma utwory fortepianowe, koncerty oraz dzieła operowe. Podczas pobytu w Carlsruhe na przełomie lat 1806/07 skomponował dwie symfonie, koncert waltorniowy i wariacje fortepianowe op. 7. Przypuszcza się, że mógł znaleźć tutaj również inspiracje do jednego ze swoich najsłynniejszych dzieł - opartego na motywach ludowych opery „Wolny strzelec” (Gosławska 2015: 122-124). 
Równolegle z kształtowaniem się części rezydencjalnej rozwijała się nowa osada. Początkowo głównym zajęciem mieszkańców było rzemiosło i rolnictwo, funkcjonowały również niewielkie zakłady produkcyjne. W szczytowym okresie rozwoju miejscowość wyposażona była w szkoły (podstawowe, zawodowe i ponadpodstawową), kościoły (ewangelicki i katolicki), synagogę, szpital, liczne urzędy, obiekty infrastruktury technicznej. Produkowano tutaj ceramikę budowlaną, wełnę drzewną oraz olejki sosnowe (Schmidt 1998). Dane demograficzne odzwierciedlają dynamikę rozwoju miejscowości. W 1792 roku w Pokoju mieszkało 842 mieszkańców, w 1861 roku już 2364, a w 1944 roku liczba mieszkańców wynosiła 2800. Wśród mieszkańców dominowali ewangelicy, a katolicy stanowili ok. 1/3 liczby ludności, w Pokoju mieszkała również niewielka mniejszość żydowska (Schmidt 1998).

Znaczącym dla rozwoju i promocji Pokoju było utworzenie uzdrowiska w oparciu o walory klimatyczne, krajobrazowe i przyrodnicze miejscowości. Specjalnością otwartego w 1847 roku uzdrowiska były kąpiele wodne i parowe z dodatkiem wyciągu z igieł sosnowych. W Bad Carlsruhe leczono schorzenia reumatyczne i ginekologiczne, układu oddechowego i pokarmowego, pomagano w rekonwalescencji. Rozwojowi uzdrowiska sprzyjało odkrycie pod koniec XIX wieku źródła leczniczego o wysokiej zawartości żelaza i siarki, a także połączenie kolejowe Pokoju z Opolem i Namysłowem. Zabudowę uzdrowiskową uzupełniały stopniowo hotele i restauracje (ryc.4). Do dyspozycji kuracjuszy pozostawały rozległe tereny parkowe, mogli oni również korzystać z programu kulturalnego oraz wycieczek (Schmidt 1998; Spielvogel, Migała, Spałek 2012). O randze uzdrowiska świadczył wydany w latach 20. XX wieku przewodnik, w którym przedstawiono walory miejscowości, ofertę kuracyjną oraz opisy tras wycieczkowych (Stumpe 1927). Po 1945 roku uzdrowisko nie wznowiło działalności.

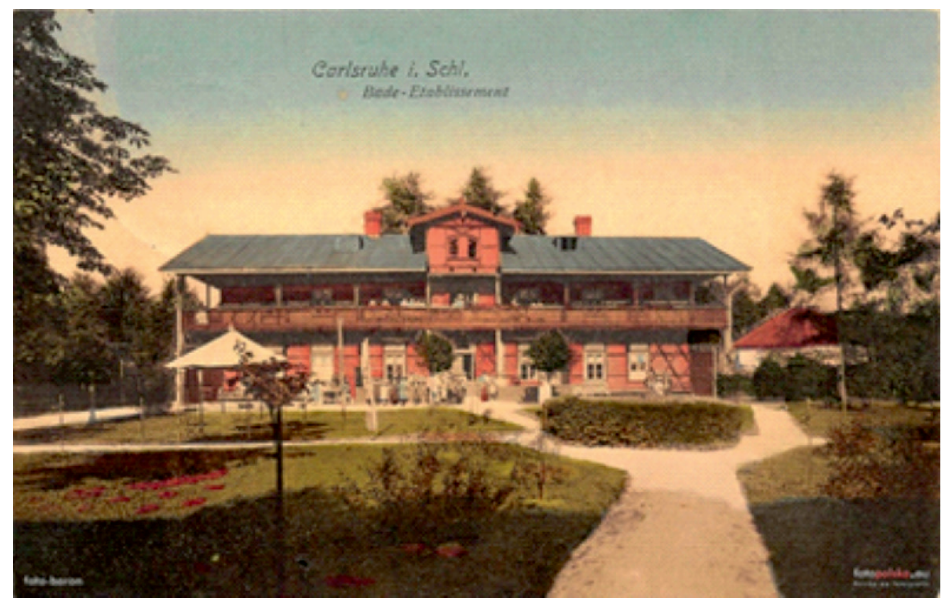

Ryc. 4. Zabudowa uzdrowiskowa Bad Carlsruhe. Domek Szwajcarski na pocz. XX wieku Źródło: https://fotopolska.eu/1342268,foto.html?o=b13093 (dostęp: 22.04.2020) 
Stosunkowo harmonijny rozwój miejscowości oparty o wielowyznaniową społeczność Pokoju został zakłócony już przed wybuchem II wojny światowej wraz prześladowaniem społeczności żydowskiej. Synagoga została zniszczona podczas Nocy Kryształowej, część rodzin wyemigrowała, pozostali Żydzi zostali eksterminowani. W okresie II wojny światowej obiekty sanatoryjne przekształcono w szpitale wojskowe i uruchomiono kilka obozów pracy. Dramatyczne przerwanie rozwoju miejscowości przyniósł koniec wojny. Stacjonujące w Pokoju zimą 1945 roku oddziały Armii Czerwonej dopuściły się nie tylko pogromu miejscowej ludności, ale również zniszczyły większość zabudowy centralnej części miejscowości. Spalona została książęca rezydencja oraz dworskie oficyny (domy kawalerskie), zabudowania uzdrowiskowe, zniszczono większość elementów architektonicznych i rzeźb w założeniach parkowych. Wiosną 1945 roku miejscowość, zniszczona i opustoszała, została przejęta przez administrację polską. Wśród podjętych w pierwszej kolejności działań znalazło się nadanie polskich nazw ulicom miejscowości (Gosławska 2015). Obecna nazwa wsi - Pokój została zatwierdzona administracyjnie w $1946 \mathrm{roku}^{7}$.

\section{Zakres i cel opracowania}

Problematyka opracowania dotyczy zachowanego dziedzictwa kulturowego ${ }^{8}$ wsi Pokój oraz działań i projektów realizowanych współcześnie przez władze gminy Pokój w kierunku ochrony i promocji tego dziedzictwa.

We wprowadzeniu zarysowano wyjątkową historię miejscowości i podkreślono jej unikalne cechy. Następnie scharakteryzowano zachowane dziedzictwo kulturowe miejscowości oraz stan jego prawnej ochrony. W dalszej części przeanalizowano zapisy o ochronie dziedzictwa miejscowości w aktualnie obowiązujących gminnych dokumentach programowych i planistycznych. Istotną częścią rozdziału jest przedstawienie projektów z udziałem środków europejskich dotyczących rewitalizacji założeń parkowych Pokoju, jak również działań dla uzyskania statusu uzdrowiska realizowanych w XXI wieku. W opracowaniu zwrócono ponadto

\footnotetext{
${ }^{7}$ Rozporządzenie Ministrów: Administracji Publicznej i Ziem Odzyskanych z dnia 12 listopada 1946 roku o przywróceniu i ustaleniu urzędowych nazw miejscowości.

${ }^{8}$ Pojęcie dziedzictwa kulturowego nie jest stałe w czasie, jego definicja przeobraża się i rozwija wraz ze zmieniającą się sytuacją społeczną, gospodarczą i polityczną. W rozumieniu Konwencji UNESCO z 1972 roku ,dziedzictwo to zabytki, zespoły i miejsca zabytkowe wyróżniające się uniwersalną, wyjątkową wartością z punktu widzenia historii, sztuki lub nauki”. Współcześnie pojęcie dziedzictwa rozszerza się na zasób wartości odziedziczony z przeszłości i stanowiący odbicie wierzeń, wiedzy i tradycji różnych społeczności. Wartość społeczną dziedzictwa podkreślają niematerialne atrybuty według definicji dziedzictwa zawartej w Konwencji UNESCO z 2003 roku (Społeczno-gospodarcze oddziaływanie dziedzictwa kulturowego... 2013: 13-14).
} 
uwagę na inicjatywy w zakresie edukacji i kultury promujące dziedzictwo Pokoju oraz budujące świadomość jego wartości i znaczenia dla rozwoju lokalnego.

Od przełomu XX i XXI wieku, po transformacji ustrojowej i ekonomicznej, wzrasta zainteresowanie przeszłością i dziedzictwem Pokoju. Pod koniec lat 90. XX wieku ukazała się pierwsza monografia Pokoju (Schmidt 1998). W XXI wieku wydano kolejną, rozszerzoną i obejmująca dzieje Pokoju od jego powstania do pierwszych dekad powojennych (Gosławska 2015). Historia Bad Carlsruhe została przedstawiona w książce o dawnych uzdrowiskach Śląska Opolskiego (Spielvogel, Migała, Spałek 2012). Autorka niniejszego rozdziału analizowała rolę wartości dziedzictwa kulturowego i środowiska przyrodniczego w lokalnym rozwoju terytorialnym wsi Pokój (Adamska 2017), a w monograficznym opracowaniu przedstawiła nekropolie miejscowości jako świadectwo wielowyznaniowej i wielokulturowej historii miejscowości (Adamska 2018).

Współcześnie, wraz z członkostwem Polski w Unii Europejskiej oraz rosnącą świadomością wartości dziedzictwa, pojawiły się nowe możliwości i instrumenty dla ochrony i wykorzystania zasobów kulturowych Pokoju. Niniejszy rozdział stanowi próbę syntetycznego przedstawienia działań podejmowanych w XXI wieku dla ochrony i promocji dziedzictwa Pokoju. Działania te obejmują również przywracanie dawnych wartości oraz wykorzystanie dziedzictwa jako potencjału w rozwoju lokalnym i regionalnym.

\section{Dziedzictwo kulturowe Pokoju po 1945 roku, stan zachowania i prawna ochrona}

Uwarunkowania, które nastąpiły po 1945 roku, takie jak zmiana państwowości i ustroju, wymiana ludności, poczucie niepewności oraz brak środków finansowych uniemożliwiły podjęcie działań dla odbudowy. Wieloletnie zaniedbania w utrzymaniu zachowanej substancji spowodowały znaczące i w wielu przypadkach nieodwracalne zniszczenie historycznych elementów założenia rezydencjalnego Carlsruhe.

W okresie pierwszych dziesięcioleci po II wojnie światowej Pokój ulegał stopniowej degradacji. Pozostałości spalonych i zdewastowanych obiektów rezydencjalnych, uzdrowiskowych i innych publicznych rozbierano i usuwano. Tak się stało m.in. z zamkiem, oficynami dworskimi i zabudową uzdrowiska. Nieliczne zachowane, a związane $\mathrm{z}$ dawną funkcją rezydencjalną obiekty pozostawały nieużytkowane i stopniowo niszczały, jak pałacyk na Winnej Górze. Założenia parkowe były pozbawione bieżącego utrzymania i opieki. Zatarciu ulegały układy kompozycyjne, następował niekontrolowany rozrost roślinności, niszczały elementy parkowej architektury i rzeźby (Gosławska 2015). Pomimo wielkiej skali zniszczeń i powojennej degradacji, szczególna i wyjątkowa przeszłość miejscowości nie została całkiem zatarta. W znacznym stopniu zachował się unikalny 
układ przestrzenny dawnego Carlsruhe, czytelnych jest siedem z ośmiu promienistych ulic oraz okrągły plac, obecnie bez zabudowy, o funkcji komunikacyjnego ronda (fot. 1). Istotnymi dla ciągłości historii i tożsamości miejscami są obiekty sakralne: barokowy, ewangelicki kościół Zofii (arch. G.L. Schirmeister) (fot. 2) i neobarokowy katolicki kościół z początku XX wieku (arch. L. Schneider), położone na historycznych alejach i tworzące sakralną oś Pokoju. Świadectwo wielowyznaniowej przeszłości miejscowości stanowią trzy cmentarze: ewangelicki, katolicki i żydowski (częściowo zlikwidowany w latach 60. XX wieku) (Adamska 2018). Wśród zabudowy mieszkalnej zachowały się charakterystyczne XVIII-wieczne parterowe domy o wysokich naczółkowych dachach (fot. 3) oraz XIX-wieczne budynki o elewacjach z czerwonej cegły ceramicznej. Spójny formalnie zespół obiektów stacyjnych z przełomu wieków wpisuje się w kanony architektury kolejowej tego okresu. Historyczne założenia parkowe o powierzchni ok. 200 ha, choć w części o nieczytelnym układzie kompozycyjnym i zdegradowanym wyposażeniu, są nadal niesłychanie ostrym i wyjątkowym wyróżnikiem przestrzeni Pokoju o silnym potencjale turystycznym. Usytuowanie obiektów dziedzictwa kulturowego Pokoju w układzie przestrzennym miejscowości ilustruje ryc. 5 .

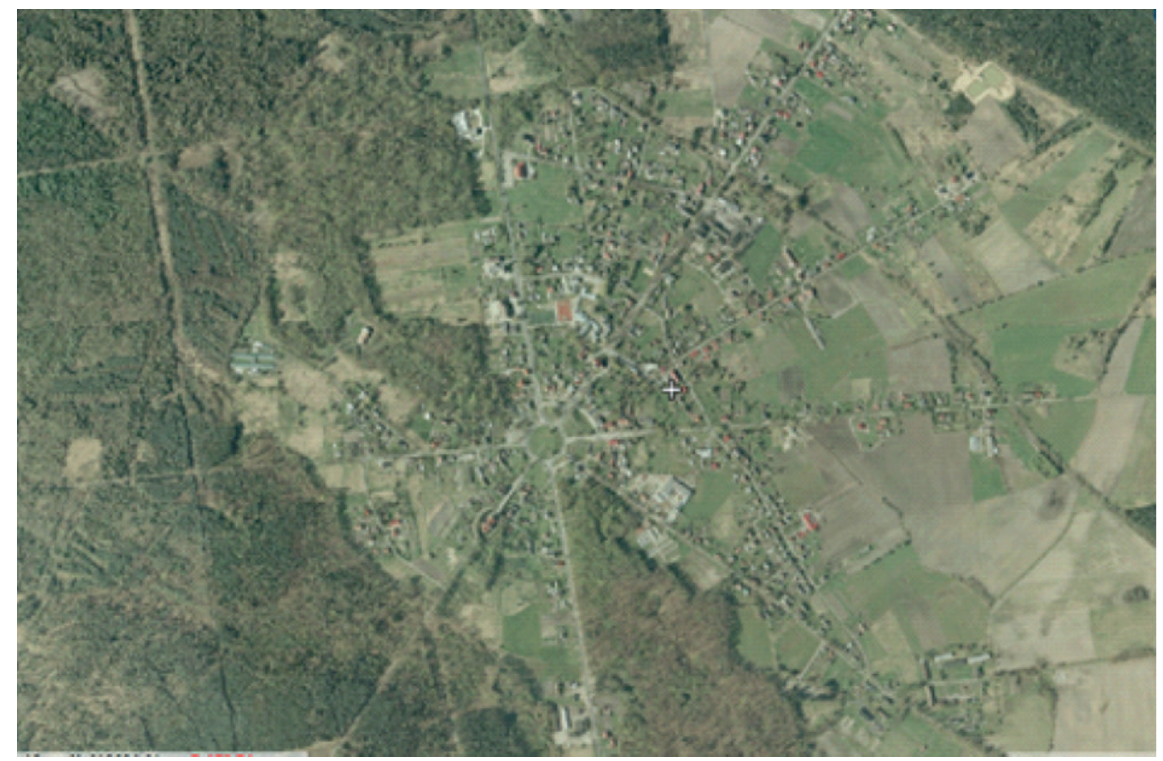

Fot. 1. Promienisto-koncentryczny układ urbanistyczny wsi Pokój, zachowanych siedem z ośmiu promienistych ulic oraz okrągły plac, obecnie bez zabudowy, o funkcji komunikacyjnego ronda

Źródło: http://maps.opolskie.pl/OGIS/default.aspx?gpw=e80bbe29-2a28-4d91-

9ace-3c72f0fb8c5f (dostęp: 22.07.2020) 


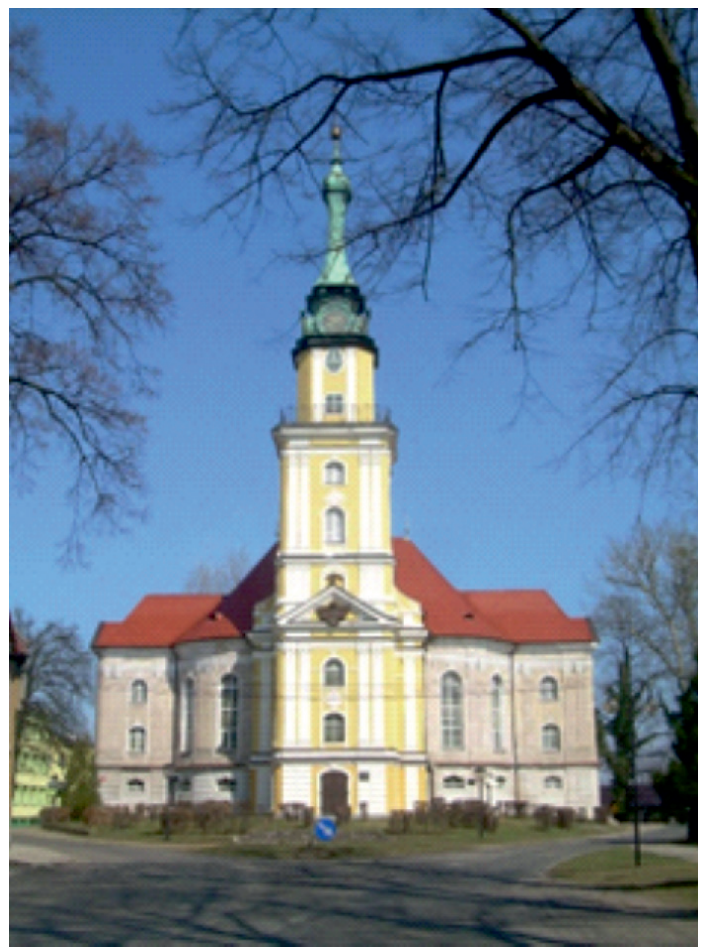

Fot. 2. Barokowy kościół ewangelicki Zofii Źródło: fot. M.E. Adamska (2011)

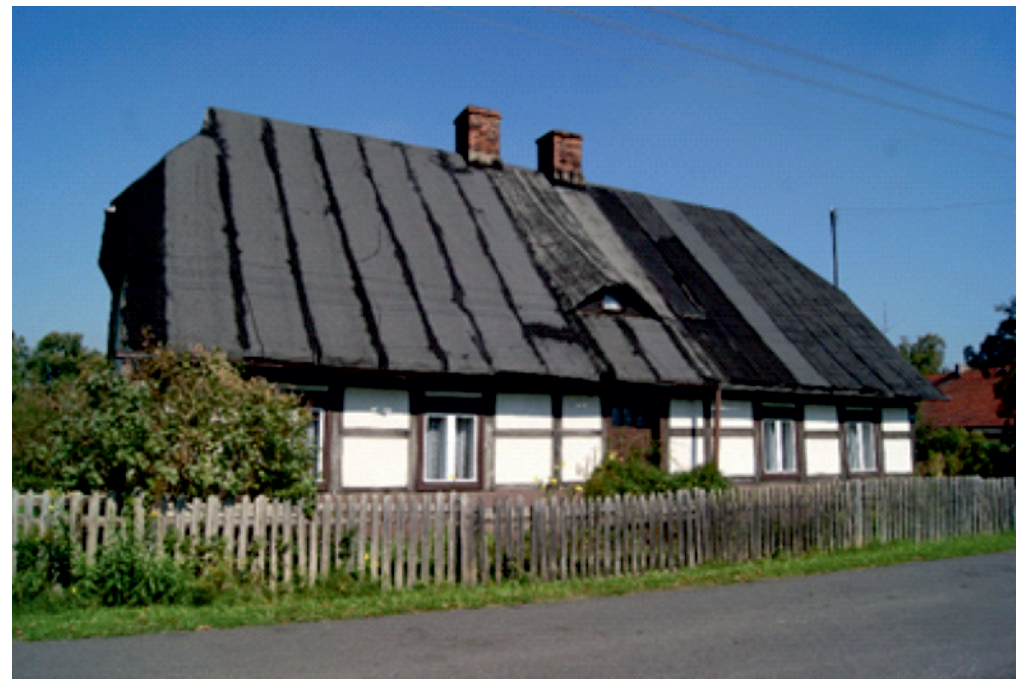

Fot. 3. XVIII-wieczny dom mieszkalny przy ul. Krzywej 4 (wpisany do rejestru zabytków nieruchomych województwa opolskiego) Źródło: fot. M.E. Adamska (2010) 


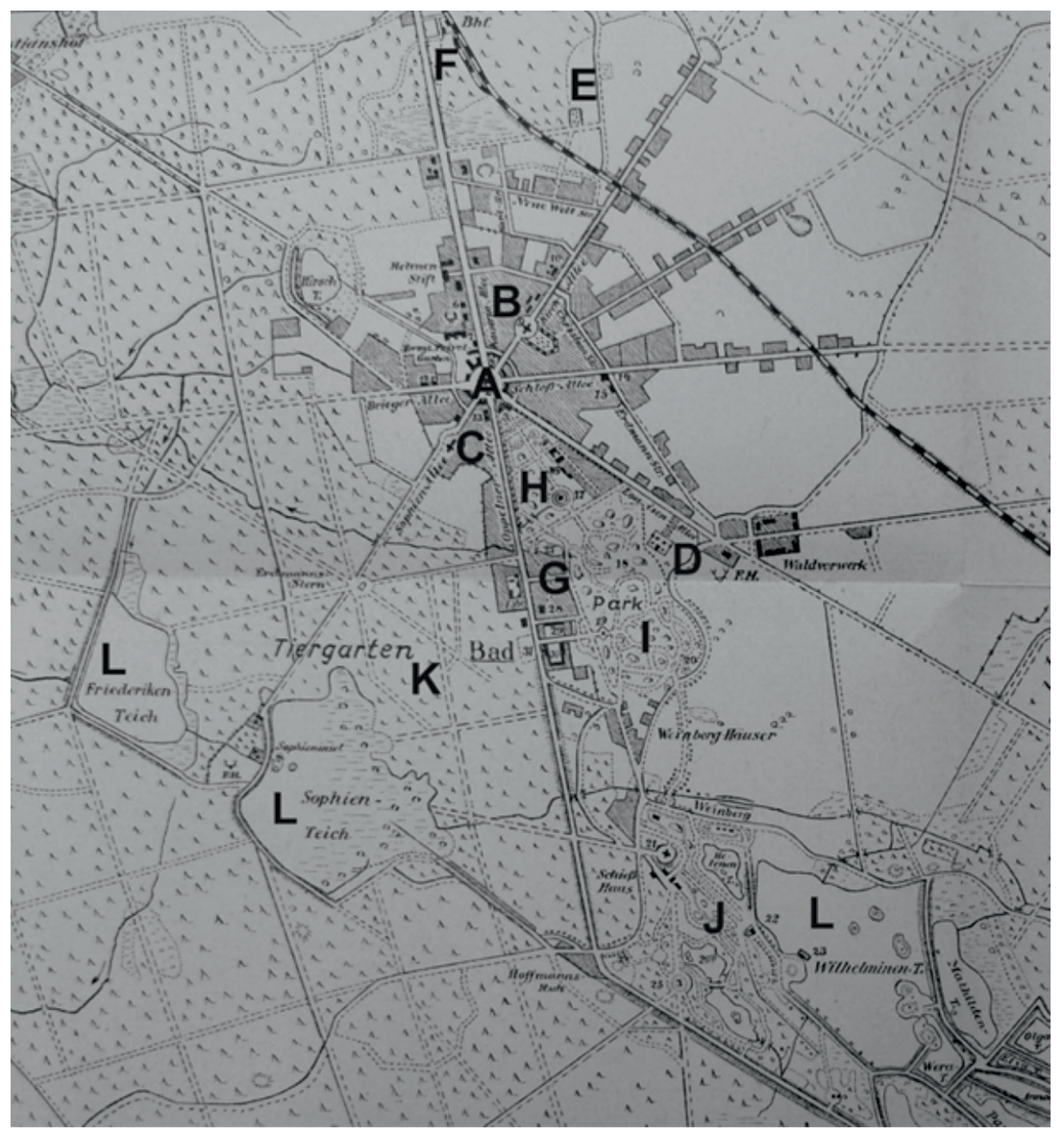

Ryc. 5. Usytuowanie zachowanych i nieistniejących obiektów dziedzictwa kulturowego Pokoju w układzie przestrzennym miejscowości: A - pałac (nieistniejący), B - kościół ewangelicki Zofii z cmentarzem, C - kościół katolicki, D - cmentarz katolicki, E - cmentarz żydowski, F - zespół obiektów stacyjnych, $\mathrm{G}$ - uzdrowisko (nieistniejące), $\mathrm{H}$ - park francuski, I - mały park angielski, $\mathrm{J}$ - duży park angielski, K - zwierzyniec (nieistniejący), L - stawy Źródło: oprac. własne na podstawie planu Carlsruhe zamieszczonego w: F. Stumpe (1927)

Proces objęcia prawną ochroną zachowanego dziedzictwa kulturowego Pokoju rozpoczął się w 1946 roku. Wpisano wówczas do rejestru zabytków kościół ewangelicki oraz park. W latach 60. XX wieku ochroną rejestrową objęto sześć, w większości XIX-wiecznych, budynków mieszkalnych oraz dawną plebanię z XVIII wieku. Trzy nekropolie miejscowości zostały wpisane do rejestru zabytków województwa opolskiego w latach 80. i 90. XX wieku. Neobarokowy kościół katolicki oraz międzywojenny dom parafialny zostały włączone do grupy rejestro- 
wych zabytków województwa w XXI wieku. Łącznie w rejestrze zabytków nieruchomych województwa opolskiego znajduje się obecnie 14 obiektów położonych w Pokoju (tab. 1) ${ }^{9}$.

Tabela 1. Wykaz obiektów w Pokoju wpisanych do rejestru zabytków nieruchomych województwa opolskiego

\begin{tabular}{|c|c|c|c|}
\hline Obiekt i adres & $\begin{array}{c}\text { Data } \\
\text { powstania }\end{array}$ & $\begin{array}{l}\text { Rok wpisu } \\
\text { do rejestru }\end{array}$ & $\begin{array}{c}\text { Nr decyzji o wpisie } \\
\text { do rejestru }\end{array}$ \\
\hline $\begin{array}{l}\text { Kościół ewangelicki } \\
\text { „Kościół Zofii” }\end{array}$ & 1775 & $\begin{array}{l}1946 \\
1956 \\
\end{array}$ & $\begin{array}{c}601 / 17 / 46 \text { z } 16.12 .1946 \\
202 / 56 \text { z } 6.10 .1956\end{array}$ \\
\hline Park & XVIII-XIX w. & $\begin{array}{l}1946 \\
1985\end{array}$ & $\begin{array}{c}7 / 46 \text { z } 16.12 .1946 \\
123 / 85 \text { z } 22.01 .1985\end{array}$ \\
\hline Dom „Mateusza”, ul. Brzeska 1 & XVIII w. & 1966 & $1795 / 66$ z 14.10 .1966 \\
\hline Dom (ruina), ul. Brzeska 20 & XIX w. & 1966 & $1796 / 66$ z 14.10 .1966 \\
\hline Dom, ul. Kościelna 1 & XIX w. & 1966 & $1797 / 66$ z 14.10 .1966 \\
\hline Dom (plebania), ul. 1 Maja 12 & XVIII w. & 1966 & $1798 / 66$ z 14.10 .1966 \\
\hline Dom, ul. 1 Maja 18 & XVIII w. & 1966 & $1801 / 66$ z 14.10 .1966 \\
\hline Dom, ul. Namysłowska 5 & XIX w. & 1966 & $1799 / 66$ z 14.10 .1966 \\
\hline Dom, ul. Wolności 36 & XIX w. & 1966 & $1800 / 66$ z 14.10 .1966 \\
\hline $\begin{array}{l}\text { Cmentarz żydowski, } \\
\text { ul. Kolejowa }\end{array}$ & ok. 1870 & 1989 & $227 / 89$ z 4.12 .1989 \\
\hline $\begin{array}{l}\text { Cmentarz parafialny, } \\
\text { ul. Wolności }\end{array}$ & 1907 & 1992 & 285/92 z 23.10.1992 \\
\hline $\begin{array}{l}\text { Cmentarz ewangelicko-augs- } \\
\text { burski, ul. } 1 \text { Maja }\end{array}$ & 2 poł. XVIII w. & 1992 & 289/92 z 28.10.1992 \\
\hline Dom parafialny, ul. 1 Maja 11 & lata 20. XX w. & 2011 & $162 / 2011$ z 7.07 .2011 \\
\hline $\begin{array}{l}\text { Kościół pw. Podwyższenia } \\
\text { Krzyża Świętego }\end{array}$ & pocz. XX w. & 2015 & $230 / 2015$ z 14.01 .2015 \\
\hline \multicolumn{4}{|c|}{$\begin{array}{l}\text { Źródło: oprac. autorki na podstawie „Wykazu obiektów zabytkowych nieruchomych wpi- } \\
\text { sanych do rejestru zabytków województwa opolskiego - stan na dzień } 15 \text { marca } 2020 \text { roku” } \\
\text { oraz literatury przedmiotu opracowania. Obiekty przedstawiono w kolejności chronolo- } \\
\text { gicznej według roku wpisu do rejestru. }\end{array}$} \\
\hline
\end{tabular}

${ }^{9}$ „Wykaz obiektów zabytkowych nieruchomych wpisanych do rejestru zabytków województwa opolskiego" - stan na dzień 15 marca 2020 r. 
Obowiązująca Ustawa o ochronie zabytków i opiece nad zabytkami z 2003 r. ${ }^{10}$ jako jedną z form ochrony zabytków wskazuje ustalenia ochrony w miejscowym planie zagospodarowania przestrzennego. Unikalny w skali Polski gwiaździsty układ urbanistyczny miejscowości został objęty ochroną w rozumieniu powyższej Ustawy ustaleniami Miejscowego planu zagospodarowania przestrzennego wsi Pokój uchwalonego w 2016 roku $^{11}$. W miejscowym planie objęto ochroną konserwatorską w sumie 38 obiektów ujętych w Gminnej Ewidencji Zabytków, w tym, obok układu przestrzennego, m.in. dworzec kolejowy, wodociągową wieżę ciśnień, domy mieszkalne, elementy parkowej architektury i rzeźby nie objęte wcześniej wpisami rejestrowymi.

\section{Dziedzictwo kulturowe Pokoju w dokumentach gminnych}

Gmina Pokój utworzona w 1973 roku, o powierzchni 133 km², jest jedną z pięciu gmin wchodzących w skład powiatu namysłowskiego. Jej strukturę przestrzenną charakteryzują duże obszary terenów leśnych (Stobrawski Park Krajobrazowy i obszar chronionego krajobrazu Lasy Stobrawsko-Turawskie) oraz doliny rzek: Stobrawy i jej dopływów. Gminę Pokój cechuje regularna sieć osadnicza, którą tworzy 13 wsi sołeckich i 5 przysiółków zamieszkanych łącznie przez 5070 mieszkańców. Wieś Pokój licząca ponad 1400 mieszkańców jest siedzibą władz samorządowych gminy oraz jej centrum kulturalno-gospodarczym ${ }^{12}$.

Dziedzictwo kulturowe gminy to w znaczącej części dziedzictwo kulturowe wsi Pokój wynikające z wyjątkowej przeszłości miejscowości. Wśród 20 rejestrowych zabytków na terenie gminy, 14 znajduje się w Pokoju (dawnym Carlsruhe). Gminną Ewidencję Zabytków tworzy blisko 100 obiektów, z których ponad 1⁄3 zlokalizowana jest w Pokoju. Wśród obiektów ujętych w wykazie z terenów innych wsi gminy Pokój stosunkowo liczną grupę stanowią kapliczki charakterystyczne dla obszarów wiejskich Opolszczyzny oraz domy mieszkalne ${ }^{13}$.

\section{Dokumenty programowe}

Zgodnie z Ustawa o ochronie zabytków i opiece nad zabytkami z 2003 roku, władze gminne mają obowiązek opracowania gminnego programu opieki nad zabytkami.

${ }^{10}$ Ustawa z dnia 23 lipca 2003 roku o ochronie zabytków i opiece nad zabytkami (Dz.U., 2003, nr 162, poz. 1568).

${ }^{11}$ Uchwała nr XXII/187/2016 Rady Gminy Pokój z dnia 12 października 2016 roku w sprawie zmiany Miejscowego planu zagospodarowania przestrzennego wsi Pokój.

${ }^{12}$ https://gminapokoj.pl/ (dostęp: 15.04.2020).

${ }^{13}$ Gminny Program Opieki nad Zabytkami Gminy Pokój na lata 2016-2019. Aneks nr 1 - Gminna Ewidencja Zabytków. 
Gminny Program Opieki nad Zabytkami Gminy Pokój na lata 2016-2019 zawiera ocenę stanu dziedzictwa kulturowego gminy przeprowadzoną z wykorzystaniem analizy SWOT. Jako słabe strony wskazano w ocenie m.in. brak wystarczających środków finansowych gminy na ochronę zabytków i prace konserwatorskie przy obiektach. Do słabych stron należą również wysokie koszty utrzymania i remontów obiektów zabytkowych oraz niski poziom wiedzy na temat dziedzictwa kulturowego. Silną stronę stanowią walory kulturowe i przyrodnicze gminy. Wśród szans wymieniono m.in. możliwość rewaloryzacji obiektów zabytkowych z wykorzystaniem dotacji krajowych i unijnych oraz rosnącą świadomość znaczenia dziedzictwa kulturowego. Zagrożenia wynikają głównie z niepozyskania zewnętrznego finansowania dla planowanych inwestycji, niedostatku środków publicznych na rewitalizację oraz niekontrolowanych działań inwestycyjnych i modernizacyjnych.

W Gminnym Programie Opieki nad Zabytkami Gminy Pokój na lata 20162019 wyznaczono kierunki działań programu opieki, w tym:

- realizację zadań z zakresu opieki nad zabytkami wynikających ze Strategii Rozwoju Gminy Pokój (rewaloryzacja zabytkowego założenia parkowego w Pokoju oraz remonty zabytków ruchomych i nieruchomych wpisanych do rejestru zabytków);

- realizację kierunków polityki przestrzennej wskazanych w Studium uwarunkowań $i$ kierunków zagospodarowania przestrzennego oraz zapisów dotyczących ochrony dziedzictwa i krajobrazu kulturowego w miejscowych planach zagospodarowania przestrzennego;

- podejmowanie starań o dofinansowanie prac przy obiektach zabytkowych z budżetu państwa (programy operacyjne) oraz programów UE;

- interwencję władz gminy przy rażących naruszeniach prawa budowlanego na obszarach objętych ochroną konserwatorską, przy obiektach wpisanych do rejestru zabytków oraz znajdujących się w gminnej ewidencji zabytków;

- realizację działań informacyjnych, popularyzacyjnych i edukacyjnych związanych z promocją zabytków i walorów krajobrazu kulturowego Pokoju.

Dokumentem gminnym odnoszącym się bezpośrednio do problematyki dziedzictwa kulturowego gminy jest Strategia Ochrony Dziedzictwa Kulturowego Gminy Pokój na lata 2016-2020. Nadrzędnym celem Strategii jest ochrona dziedzictwa kulturowego gminy oraz wzrost znaczenia zabytków gminy dla jej rozwoju. Ponadto w Strategii sformułowano cztery cele szczegółowe:

- zachowanie dziedzictwa materialnego;

- świadome kształtowanie krajobrazu kulturowego, w tym kultywowanie tradycji regionalnych;

- promocja i upowszechnianie szeroko pojętego dziedzictwa kulturowego;

- zwiększenie świadomości społecznej i edukacja służąca budowaniu tożsamości. 
Dokumentem określającym wizję i ogólne kierunki rozwoju gminy jest Strategia Rozwoju Gminy Pokój na lata 2014-2020. Dokument zawiera odniesienie do potencjału turystycznego i uzdrowiskowego dziedzictwa kulturowego wsi Pokój. Tekst uchwalonego w 2014 roku dokumentu ${ }^{14}$ wzmiankuje o planowanej rewitalizacji historycznego założenia parkowego Pokoju, jako działaniu mogącym wzmocnić atrakcyjność turystyczną gminy. W dokumencie wskazano potencjał uzdrowiskowy Pokoju jako ważną oś rozwoju gminy oraz przedstawiono zrealizowane działania dla uzyskania statusu uzdrowiska. W województwie opolskim nie ma obecnie obszarów o statusie uzdrowiska.

\section{Dokumenty planistyczne}

W 2012 roku została uchwalona zmiana Studium uwarunkowań i kierunków zagospodarowania przestrzennego gminy Pokój dla obszaru wsi Pokój ${ }^{15}$.

W części „Uwarunkowania” znalazły się zapisy o walorach i predyspozycjach miejscowości ze wskazaniem m.in. na funkcje turystyczne i lecznicze. Wśród działań istotnych dla rozwoju wsi, odnoszących się do jej dziedzictwa kulturowego i przyrodniczego wymieniono:

- zachowanie wartościowych zasobów przyrodniczych i kulturowych zabytkowych parków;

- ochronę zabytkowych obiektów architektury i budownictwa;

- ochronę unikalnego gwiaździstego układu przestrzennego wsi;

- respektowanie zasad gospodarowania określonych dla ustalonych stref ochrony konserwatorskiej;

- ochronę pomników przyrody;

- utworzenie proponowanych form ochrony w postaci zespołu przyrodniczo-krajobrazowego i parku kulturowego.

W części „Kierunki zagospodarowania przestrzennego gminy - polityka przestrzenna" wskazano obszary do ustanowienia ochrony w miejscowym planie zagospodarowania przestrzennego oraz propozycje zapisane w ówcześnie obowiązującym Planie zagospodarowania przestrzennego województwa opolskiego:

- objęcie ochroną w postaci uznania za pomnik historii obiektu zabytkowego pn. „Pokój - kościół ewangelicki”;

- objęcie ochroną w postaci utworzenia parku kulturowego pn. „Zespół parkowo-ruralistyczny - Pokój” w obszarze strefy ochrony konserwatorskiej „A”.

${ }^{14}$ Strategia Rozwoju Gminy Pokój na lata 2014-2020 przyjęta Uchwałą Nr XXXVII/ 323/2014 Rady Gminy Pokój z dnia 7 listopada 2014 r.

${ }^{15}$ Uchwała Nr XVIII/153/2012 Rady Gminy Pokój z dnia 26 listopada 2012 roku w sprawie uchwalenia zmiany Studium uwarunkowań $i$ kierunków zagospodarowania przestrzennego gminy Pokój dla obszaru wsi Pokój. 
W zmianie Studium sformułowano również kierunki i działania dla ochrony zabytkowych parków Pokoju, w tym: rekonstrukcję układów kompozycyjnych, elementów systemu wodnego oraz parkowej architektury i rzeźby oraz wprowadzenie nowych nasadzeń wraz z gospodarką istniejącym drzewostanem.

W 2016 roku uchwalono zmianę Miejscowego planu zagospodarowania przestrzennego wsi Pokój ${ }^{16}$. Plan obejmuje część obrębu ewidencyjnego wsi o powierzchni 1040 ha. Znaczną część powierzchni obszaru planu poza obszarem zabudowanym zajmują kompleksy leśne oraz historyczne założenia parkowe i stawy. W planie określono zasady ochrony dziedzictwa kulturowego i zabytków miejscowości Pokój, w tym krajobrazów kulturowych oraz ustanowiono następujące obszary ochrony konserwatorskiej:

- strefa „A" ochrony konserwatorskiej historycznego układu urbanistycznego obejmuje obszar dawnego założenia pałacowego i domów kawalerskich, otoczenie kościołów ewangelickiego i katolickiego oraz historyczne parki: Park Przypałacowy (tzw. park francuski), Park Uzdrowiskowy (tzw. mały park angielski), zaplecze Parku Przypałacowego (tzw. teren ogrodnictwa), Ogród Książęcy (d. menażerię), Ogród Angielski (tzw. duży park angielski) oraz obszar komponowanych krajobrazów (wg granic oznaczonych na rysunku planu);

- strefa „B” ochrony konserwatorskiej krajobrazu kulturowego wsi Pokój z radialnym układem przestrzennym;

- strefa „K” ochrony konserwatorskiej krajobrazu kulturowego (obejmuje część obszaru Książęcego Zwierzyńca w historycznych granicach).

\section{Dzialania i projekty w kierunku ochrony i promocji dziedzictwa kulturowego Pokoju oraz rozwoju miejscowości}

\section{Wybrane projekty z udziałem środków europejskich}

Gmina Pokój z powodzeniem aplikowała o środki europejskie dla realizacji projektów w obszarze działań edukacyjnych, społecznych i technicznych już w okresie programowania 2007-2013. W ramach Regionalnego Programu Operacyjnego Województwa Opolskiego (RPO WO) zrealizowano wówczas rozbudowę kanalizacji sanitarnej w Pokoju (I etap) ${ }^{17}$. Środki Programu Rozwoju Obszarów Wiejskich przyczyniły się do utworzenia Izby Regionalnej

${ }^{16}$ Uchwała nr XXII/187/2016 Rady Gminy Pokój z dnia 12 października 2016 roku w sprawie zmiany Miejscowego planu zagospodarowania przestrzennego wsi Pokój. Plan opracowano w Pracowni Architektury i Urbanistyki „Na Wyspie”, autorzy: arch. Krystyna Kucharzewska, arch. Monika Adamska.

${ }^{17}$ https://gminapokoj.pl/1546/2007/rozbudowa-kanalizacji-sanitarnej-w-pokoju-etap-i.html (dostęp: 15.02.2020). 
w Pokoju ${ }^{18}$, wydania publikacji Jesteśmy stąd. Gmina Pokój z bliska ${ }^{19}$ oraz organizacji „III Stobrawskiego Święta Produktów Lokalnych”20 promującego tradycyjne produkty i usługi.

Władze gminy Pokój intensywnie i skutecznie aplikują o środki europejskie w okresie programowania 2014-2020. W obszarze ochrony i promocji dziedzictwa kulturowego miejscowości Pokój, a w szczególności historycznego założenia parkowego, wyróżniają się projekty realizowane w ramach RPO WO 2014-2020 (tab. 2).

Tabela 2. Wybrane projekty realizowane przez gminę Pokój w obszarze ochrony i promocji dziedzictwa kulturowego miejscowości w ramach Regionalnego Programu Operacyjnego Województwa Opolskiego 2014-2020 (Europejski Fundusz Rozwoju Regionalnego). Oś priorytetowa V: Ochrona środowiska, dziedzictwa kulturowego i naturalnego

Nazwa projektu, działanie, wartość projektu i dofinansowanie z UE, okres realizacji projektu

Zachowanie dziedzictwa kulturowego i historycznego poprzez rewaloryzacje obiektów zabytkowych w Pokoju i działania edukacyjno-informacyjne w województwie opolskim Działanie 5.3. Ochrona dziedzictwa kulturowego i kultury

Wartość projektu: 3800 000,00 zł; Dofinansowanie z UE: 3230 000,00 zł (85\%) Okres realizacji projektu: 2017-05-2019-06

Zachowanie różnorodności biologicznej obszarów chronionych Opolszczyzny poprzez ochronę zagrożonych gatunków, siedlisk, pielęgnację i tworzenie nowych form ochrony na terenie zabytkowego zalożenia parkowego w Pokoju

Działanie 5.1. Ochrona różnorodności biologicznej

Wartość projektu: 2805000 zł; Dofinansowanie z UE: 2384250 zł (85\%)

Okres realizacji projektu: 2017-12-22-2020-12-19

Inwentaryzacja przyrodnicza parku w Gieralcicach, ochrona in situ w zabytkowym parku w Pokoju oraz działania edukacyjno-promocyje

Działanie 5.1. Ochrona różnorodności biologicznej

Wartość projektu: 4334 599,00 zł; Dofinansowanie z UE: 3684 409,15 zł (85\%)

Okres realizacji projektu: 2019-08-01-2023-12-31

Ochrona in situ w zabytkowym zalożeniu parkowym oraz przeprowadzenie inwentaryzacji dendrologicznej na obszarze gminy Pokój i działania informacyjno-edukacyjne

Działanie 5.1. Ochrona różnorodności biologicznej

Wartość projektu: 4542020 zł; Dofinansowanie z UE: 3860717 zł (85\%)

Okres realizacji projektu: 2020-01-01-2021-12-31

${ }^{18} \mathrm{http}$ ://izbaregionalnapokoj.pl/4/57/historia-izby-regionalnej.html (dostęp: 15.02.2020).

${ }^{19}$ https://gminapokoj.pl/846/1109/perla-na-stobrawskim-zielonym-szlaku.html (dostęp: 15.02.2020).

${ }^{20} \mathrm{https}$ ://gminapokoj.pl/1564/2029/iii-stobrawskie-swieto-produktow-lokalnych.html (dostęp: 15.02.2020). 
Tabela 2 (cd.)

Zachowanie różnorodności biologicznej obszarów chronionych Opolszczyzny poprzez ochronę zagrożonych gatunków, siedlisk, pielegnację i tworzenie nowych form ochrony na terenie zabytkowego zalożenia parkowego w Pokoju. Etap II

Działanie 5.1. Ochrona różnorodności biologicznej

Wartość projektu: 4149 703,07 zł; Dofinansowanie z UE: 3527 247,60 zł (85\%)

Okres realizacji projektu: 2020-02-28-2021-12-31

Ochrona różnorodności biologicznej poprzez przeprowadzenie reintrodukcji gatunków rodzimych $w$ zabytkowym parku $w$ Pokoju oraz stworzenie warunków dla bytowania płazów w Dąbrowie i działania z zakresu edukacji ekologicznej

Działanie 5.1. Ochrona różnorodności biologicznej

Wartość projektu: 2668 494,42 zł; Dofinansowanie z UE: 2210 682,91 zł (83\%)

Okres realizacji projektu: 2022-01-01-2023-12-31

Źródło: oprac. autorki na podstawie źródeł internetowych: https://mapadotacji.gov.pl/projekty/ (dostęp: 15.02.2020); https://gminapokoj.pl/ (dostęp: 15.02.2020). Projekty przedstawiono w kolejności chronologicznej według rozpoczęcia realizacji.

Wśród tych przedsięwzięć szczególnie interesujący jest projekt o holistycznym charakterze Zachowanie dziedzictwa kulturowego i historycznego poprzez rewaloryzację obiektów zabytkowych i działania edukacyjno-informacyjne w województwie opolskim, realizowany przez gminę Pokój jako lidera oraz czterech partnerów ${ }^{21}$. W ramach projektu przewiduje się następujące działania:

- konserwację i odbudowę wybranych elementów małej architektury (figury i pomniki) oraz budowli (m.in. dawny salon wodny oraz świątynia księcia Wilhelma Eugena) na terenie założenia parkowego w Pokoju;

- konserwację i odbudowę ogrodzenia zabytkowego założenia parkowego w Pokoju;

- działania edukacyjno-informacyjne (warsztaty, programy, publikacje);

- wydarzenia promocyjne (konferencje, multimedialny atlas-przewodnik) ${ }^{22}$.

Inne projekty realizowane $w$ ramach RPO WO 2014-2020 i jego osi priorytetowej „Ochrona środowiska, dziedzictwa kulturowego i naturalnego” obejmują liczne działania dedykowane środowisku przyrodniczemu historycznego założenia parkowego w Pokoju, a wśród nich:

- inwentaryzacja dendrologiczna;

- gospodarka drzewostanem i prace agrotechniczne;

${ }^{21}$ Gmina Pokój jako lider projektu działa w partnerstwie z Wojewódzkim Urzędem Pracy w Opolu, Państwową Wyższą Szkołą Zawodową w Nysie, Opolskim Wojewódzkim Konserwatorem Zabytków w Opolu oraz Gminnym Ośrodkiem Kultury, Rekreacji i Sportu w Pokoju.

${ }^{22}$ https://gminapokoj.pl/3485/2150/zachowanie-dziedzictwa-kulturowego-i-historycznego-poprzez-rewaloryzacje-obiektow-zabytkowych-i-dzialania-edukacyjno-informacyjne-w-wojewodztwie-opolskim.html (dostęp: 15.02.2020). 
- objęcie ochroną prawną drzew;

- nasadzenia roślin w celu zwiększenia różnorodności biologicznej;

- reintrodukcja gatunków rodzimych (m.in. buk zwyczajny, grab pospolity, kalina koralowa, kosaciec syberyjski, konwalia majowa);

- stworzenie warunków siedliskowych dla organizmów wodnych;

- utworzenie ścieżek przyrodniczo-edukacyjnych ${ }^{23}$.

Gmina Pokój podejmuje również działania o mniejszej skali, dofinansowane $\mathrm{z}$ innych funduszy europejskich. Dzięki pomocy Europejskiego Funduszu Rolnego i Programu Rozwoju Obszarów Wiejskich na lata 2014-2020, w ramach projektu Nie było nas, byt las w 2018 roku nasadzono 30 lip dla odtworzenia i uzupełnienia historycznych szpalerów drzew wzdłuż ulic Pokoju oraz przeprowadzono działania dla edukacji ekologicznej ${ }^{24}$. Środki Europejskiego Funduszu Morskiego i Rybackiego, w ramach programu „Rybactwo i Morze” na lata 2014-2020 pozwoliły na dofinansowanie w $85 \%$ operacji Rewaloryzacja terenów przyległych do cieków w zabytkowym parku w Pokoju, polegającej na oczyszczeniu zbiorników wodnych oraz rowów na terenie historycznego założenia parkowego celem odtworzenia pierwotnego stanu środowiska ${ }^{25}$.

\section{Działania w kierunku uzyskania statusu uzdrowiska}

Znaczące w wielowątkowej historii Pokoju są dzieje Bad Carlsruhe - znanego i cenionego na Śląsku uzdrowiska. Kurort, otwarty w połowie XIX wieku i funkcjonujący do czasów II wojny światowej, sprzyjał rozwojowi i promocji miejscowości.

W XXI wieku zainicjowane zostały działania, zarówno formalne, jak i realizacyjne, mające na celu uzyskanie przez Pokój statusu uzdrowiska. List intencyjny w sprawie reaktywowania działalności uzdrowiskowej w Pokoju podpisali w 2002 roku Marszałek Województwa Opolskiego, Wojewoda Opolski oraz Wójt Gminy Pokój.

Uzyskanie statusu uzdrowiska jest złożonym procesem uwarunkowanym spełnieniem szeregu wymagań. Zgodnie z polskim prawem, status uzdrowiska może być nadany obszarowi, który spełnia łącznie następujące warunki:

- posiada złoża naturalnych surowców leczniczych o potwierdzonych właściwościach leczniczych;

- posiada klimat o właściwościach leczniczych;

\footnotetext{
${ }^{23} \mathrm{https}: / /$ mapadotacji.gov.pl/projekty (dostęp: 15.02.2020).

${ }^{24}$ https://gminapokoj.pl/4028/2196/projekt-pn-nie-bylo-nas-byl-las.html (dostęp: 15.02.2020).

${ }^{25}$ https://gminapokoj.pl/4464/2203/rewaloryzacja-terenow-przyleglych-do-ciekow-w-zabytkowym-parku-w-pokoju.html (dostęp: 15.02.2020).
} 
- na jego obszarze znajdują się zakłady lecznictwa uzdrowiskowego i urządzenia lecznictwa uzdrowiskowego, przygotowane do prowadzenia lecznictwa uzdrowiskowego;

- spełnia określone w przepisach o ochronie środowiska wymagania w stosunku do środowiska;

- posiada infrastrukturę techniczną w zakresie gospodarki wodno-ściekowej, energetycznej, w zakresie transportu zbiorowego, a także prowadzi gospodarkę odpadami ${ }^{26}$.

Wśród działań zrealizowanych w ostatnich latach przez władze gminy Pokój i przybliżających perspektywę uzyskania statusu uzdrowiska należy wymienić:

- rozbudowę sieci kanalizacji sanitarnej (projekt zrealizowany w ramach RPO WO na lata 2007-2013);

- formalno-prawne przekazanie części terenów zabytkowego parku gminie Pokój (wcześniej własność Lasów Państwowych);

- opracowanie dokumentacji rewitalizacji założeń parkowych Pokoju;

- realizacja działań rewitalizacyjnych w obszarze założeń parkowych Pokoju w ramach projektów z udziałem środków unijnych ${ }^{27}$.

W odniesieniu do warunku prowadzenia lecznictwa uzdrowiskowego, władze gminy nie planują samodzielnie budowy zakładów lecznictwa, lecz zakładają stworzenie dogodnych warunków dla potencjalnego inwestora zewnętrznego. Obecnie bazę dla przyszłego lecznictwa uzdrowiskowego w Pokoju stanowi Zakład Rehabilitacji Leczniczej, o wieloletniej tradycji, stanowiący część spółki Stobrawskie Centrum Medyczne.

Złożony w spełnieniu i wymagający znacznego zaangażowania finansowego jest warunek dotyczący posiadania naturalnych surowców o potwierdzonych właściwościach leczniczych. W zakresie poszukiwania wód leczniczych w Pokoju opracowano: dokumentację geologiczną, inwentaryzację przyrodniczą oraz raport oddziaływania na środowisko. Według wykonanych opracowań prawdopodobna jest obecność w Pokoju wód termalnych oraz wód leczniczych o właściwościach wykorzystywanych do leczenia chorób reumatycznych, układu oddechowego oraz urazów narządów ruchu. Aby sprawdzić właściwości i wartości potencjalnych złóż wód leczniczych konieczne jest wykonanie dwóch otworów: badawczo-eksploatacyjnego oraz chłonnego o głębokości do $2500 \mathrm{~m}^{28}$. Wyznaczone przez specjalistów obszary położone w północnej części miejscowości, zostały

${ }^{26}$ Ustawa z dnia 28 lipca 2005 roku o lecznictwie uzdrowiskowym, uzdrowiskach i obszarach ochrony uzdrowiskowej oraz o gminach uzdrowiskowych (Dz.U., 2005, nr 167, poz. 1399).

${ }^{27}$ https://opowiecie.info/dla-wszystkich-jestesmy-lasem-barbara-zajac-wojtem-gminy-pokoj-rozmawia-leszek-myczka/ (dostęp: 15.03.2020); http://www.gminapokoj. pl/976/rozwoj-gminy-pokoj-w-oparciu-o-uzdrowisko.html (dostęp: 15.03.2020).

${ }^{28}$ Strategia Rozwoju Gminy Pokój... op.cit. 
zapisane w miejscowym planie zagospodarowania przestrzennego z 2016 roku w zakresie przeznaczenia terenu i zasad zagospodarowania. Władze gminy uzyskały pozwolenie na wykonanie otworów. Ponieważ koszty tego działania przekraczają możliwości finansowe gminy, trwa poszukiwanie źródeł zewnętrznego finansowania tej inwestycji, m.in. jako jednego z priorytetowych projektów Obszaru Funkcjonalnego Kluczbork-Namysłów-Olesno ${ }^{29}$.

Uzyskanie statusu uzdrowiska warunkuje również posiadanie klimatu o właściwościach leczniczych poparte badaniem jakości powietrza. Walory klimatyczne i krajobrazowe Pokoju położonego w obszarze rozległych kompleksów leśnych borów stobrawskich stanowiły podstawę założonego tutaj w XIX wieku uzdrowiska. Do dzisiaj Obszar Chronionego Krajobrazu Lasy Stobrawsko-Turawskie, należący do najcenniejszych obszarów przyrodniczych Opolszczyzny, wytwarza korzystny mikroklimat. Współcześnie problem stanowi jednak zła jakość powietrza, jego zanieczyszczenie i przekroczone normy pyłów. Powodem tej sytuacji jest stosowanie systemów grzewczych o niekorzystnym wpływie na środowisko, głównie pieców i kotłów węglowych. W gminie Pokój prowadzone są działania w kierunku instalacji systemów grzewczych przyjaznych dla środowiska, jednak jest to proces długofalowy wynikający z ograniczeń ekonomicznych i formalnych ${ }^{30}$.

\section{Działania w zakresie kultury i edukacji}

Wśród innych działań promujących dziedzictwo kulturowe i przywołujących historię dawnego Carlsruhe, wyróżnia się Festiwal Muzyki Zabytkowych Parków i Ogrodów im. Carla Marii von Webera, odbywający się w Pokoju każdej wiosny od 2004 roku. Jednym z celów Festiwalu jest prezentacja twórczości wybitnego niemieckiego kompozytora doby romantyzmu Carla Marii von Webera, który przebywał w Carlsruhe w latach 1806-1807, na zaproszenie właścicieli miejscowości - książąt von Württemberg. Celem Festiwalu jest również promocja zabytkowych założeń parkowych Pokoju, wyjątkowych ze względu na swoje walory historyczne i przyrodnicze. Organizatorem Festiwalu Muzyki Zabytkowych

${ }^{29}$ Gmina Pokój jest jednym z 19 samorządów wchodzących w skład utworzonego w 2013 roku Obszaru Funkcjonalnego Kluczbork-Namysłów-Olesno (OF KNO). Głównym celem aglomeracji powiatów i gmin północnej Opolszczyzny jest m.in. wspólne pozyskiwanie środków unijnych w latach 2014-2020 na realizację celów priorytetowych każdego z członków Obszaru Funkcjonalnego. Na liście projektów indykatywnych w dokumencie programowym OF KNO znalazł się projekt zatytułowany „Utworzenie strefy uzdrowiskowo-rekreacyjnej obszaru funkcjonalnego Kluczbork-Namysłów-Olesno w oparciu o istniejące zasoby naturalne", którego liderem jest gmina Pokój (Strategia Rozwoju Obszaru Funkcjonalnego Kluczbork-Namysłów-Olesno 2015-2020).

${ }^{30} \mathrm{https}$ //opowiecie.info/dla-wszystkich-jestesmy-lasem-barbara-zajac-wojtem-gminy-pokoj-rozmawia-leszek-myczka/ (dostęp: 15.03.2020). 
Parków i Ogrodów im. Carla Marii von Webera jest Stowarzyszenie Pokój Organizacja Pożytku Publicznego ${ }^{31}$. Koncerty odbywają się we wnętrzach obiektów sakralnych Pokoju: kościele ewangelickim księżnej Zofii oraz kościele katolickim pw. Podwyższenia Krzyża, a także w ewangelickim domu parafialnym. Trwający kilka dni festiwal weberowski przyciąga nie tylko miłośników muzyki klasycznej, ale również dawnych mieszkańców Carlsruhe oraz ich rodziny ${ }^{32}$. Pobyt Carla Marii von Webera w Pokoju upamiętnia pamiątkowa tablica z okazji 200. rocznicy jego urodzin wmurowana we wnętrzu kościoła ewangelickiego w 1986 r. oraz popiersie kompozytora autorstwa opolskiego rzeźbiarza Adolfa Panitza odsłonięte przed kościołem w 2010 roku (fot. 4).

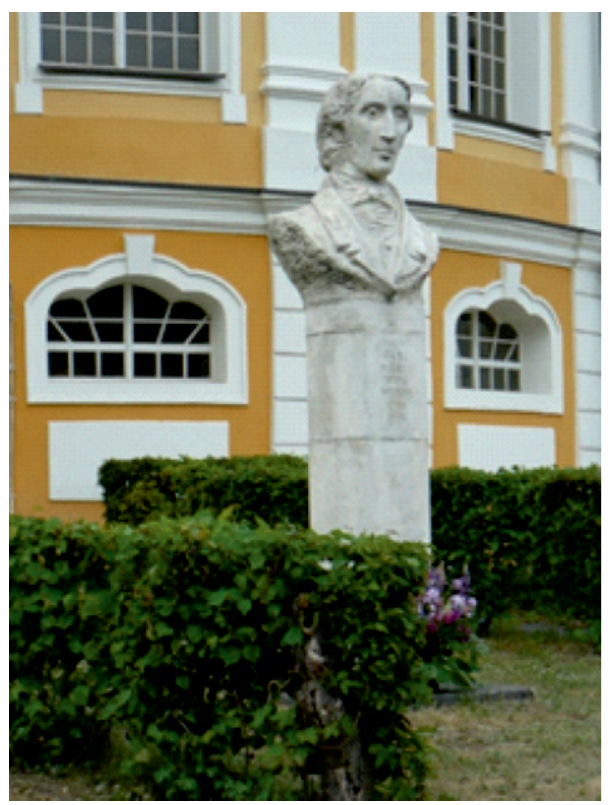

Fot. 4. Popiersie kompozytora C.M. von Webera przed kościołem ewangelickim Zofii Źródło: fot. M.E. Adamska (2016)

Znaczące są działania w zakresie edukacji regionalnej podjęte przez Zespół Szkół Gimnazjalnych w Pokoju. Nauczyciele wraz z uczniami realizowali projekty edukacyjne, których celem było pogłębienie wiedzy młodzieży o lokalnym środowisku, jego walorach przyrodniczych i dziedzictwie kulturowym. Efekty projektów i działań, w tym autorskie piesze i rowerowe ścieżki edukacyjne oraz biogramy znanych osób związanych z miejscowością, zostały przedstawione w ilustrowanej publikacji adresowanej do wszystkich zainteresowanych przeszłością i współczesnością gminy Pokój. Publikacja zatytułowana Jesteśmy stąd.

\footnotetext{
${ }^{31}$ Współorganizatorami Festiwalu są: Urząd Gminy Pokój, Parafia Ewangelicko-Augsburska w Pokoju oraz Parafia Rzymskokatolicka w Pokoju.

${ }^{32} \mathrm{http}$ ://www.gminapokoj.pl/916/779/festiwal-muzyki-zabytkowych-parkow-i-ogrodow-im-carla-marii-webera.html (dostęp: 11.03.2020).
} 
Gmina Pokój z bliska, współfinansowana ze środków Unii Europejskiej w ramach Programu Rozwoju Obszarów Wiejskich na lata 2007-2013, została wydana w 2012 roku $^{33}$.

Miejscowość i jej okolice promowane są również obrazem Pokój z wido$\mathrm{kiem}^{34}$. To 25-minutowy film zrealizowany w 2014 roku w ramach projektu ,Zielone Perły Opolszczyzny". Celem tego przyrodniczo-krajobrazowego serialu jest propagowanie i popularyzacja najciekawszych turystycznie i przyrodniczo miejsc na Opolszczyźnie. Odcinek Pokój z widokiem dotyczy Stobrawskiego Parku Krajobrazowego, a osią jego narracji jest miejscowość Pokój, jej historia, dziedzictwo kulturowe i walory przyrodniczo-krajobrazowe. Film zrealizowany przez Opolską Fundację Filmową OFFilm przyciąga uwagę nowoczesnymi formami i technikami przekazu oraz realizacji ${ }^{35}$.

\section{Podsumowanie}

Dziedzictwo kulturowe wsi Pokój (dawne Carlsruhe), pomimo wielkiej skali zniszczeń w 1945 roku oraz powojennej degradacji, jest nadal wyrazistym i unikalnym w skali regionu świadectwem wyjątkowej przeszłości miejscowości. Tożsamość Pokoju kształtują przede wszystkim: gwiaździsty układ urbanistyczny, obiekty sakralne, trzy nekropolie oraz rozległe założenia parkowe.

Wszystkie zachowane obiekty o szczególnych wartościach zabytkowych są objęte ochroną prawną poprzez wpis do rejestru zabytków województwa opolskiego oraz zapisy obowiązującego miejscowego planu zagospodarowania przestrzennego. Gwiaździsty układ urbanistyczny, wyjątkowy w skali regionu i kraju, został objęty ochroną w przywołanym planie. W perspektywie dalszych działań dla ochrony dziedzictwa Pokoju jest uznanie za pomnik historii obiektu zabytkowego pn. „Pokój - kościół ewangelicki” oraz utworzenie parku kulturowego pn. „Zespół parkowo-ruralistyczny - Pokój” w obszarze strefy ochrony konserwatorskiej „A”.

Władze gminne Pokoju z sukcesami pozyskują zewnętrzne środki finansowe. Wśród projektów realizowanych przez gminę Pokój w okresie 2014-2020 w ramach RPO WO, dominują przedsięwzięcia dotyczące rewaloryzacji założeń parkowych Pokoju w kierunku przywrócenia ich walorów kulturowych i przyrodniczych. Efektów szerokiego zakresu działań, finansowanych w znacznym stopniu ze środków europejskich, należy się spodziewać w najbliższych latach. Rewaloryzacja zespołu parkowego zdecydowanie zwiększy atrakcyjność Pokoju oraz wzmocni potencjał turystyczny gminy i regionu.

${ }^{33}$ E. Gosławska red. (2012). Publikacja została opracowana w ramach projektu „Perła na Stobrawskim Zielonym Szlaku”.

${ }^{34}$ https://www.youtube.com/watch?v=XD8wLFqrG-Q (dostęp: 12.03.2020).

${ }^{35} \mathrm{http}: / / w w w . g m i n a p o k o j . p l / 1795 / 2071 /$ film-promocyjny-pokoj-z-widokiem.html (dostęp: 12.03.2020); http://offilm.pl/ (dostęp: 12.03.2020). 
Drugi obszar działań zainicjowanych współcześnie stanowią starania o uzyskanie przez Pokój statusu uzdrowiska, które mogłoby kontynuować przedwojenne tradycje Bad Carlsruhe. Idei reaktywacji uzdrowiska w Pokoju przychylne są władze samorządowe województwa opolskiego. Konieczność spełnienia złożonych uwarunkowań prawnych dla uzyskania statusu uzdrowiska oraz potrzeba zaangażowania znacznych środków finansowych (m.in. poszukiwanie wód leczniczych) wydłuża perspektywę realizacji tego zamiaru.

Bardzo cenne są również inicjatywy i projekty w zakresie edukacji regionalnej i kultury promujące dziedzictwo Pokoju. Wśród nich wyróżniają się: cykliczny Festiwal Muzyki Zabytkowych Parków i Ogrodów im. Carla Marii von Webera oraz działania realizowane przez Zespół Szkół Gimnazjalnych w Pokoju dla poznania przez młode pokolenie historii miejscowości i jej walorów.

Pomimo intensyfikacji działań dla ochrony i rewaloryzacji dziedzictwa kulturowego Pokoju, szereg jego obszarów wymaga nadal uwagi i zaangażowania dla przywrócenia i zachowania cennych wartości. Jednym z nich są nekropolie Pokoju stanowiące wyraziste świadectwo współistnienia społeczności ewangelickiej, katolickiej i żydowskiej.

Dalsza promocja Pokoju może się wiązać z zamiarem uruchomienia nieczynnej obecnie linii kolejowej relacji Jełowa-Namysłów, która wraz z zachowanym XIX-wiecznym zespołem stacyjnym w Pokoju mogłaby służyć funkcji turystycznej. Realizacja nowej trasy drogi wojewódzkiej Opole-Namysłów, wyprowadzającej ruch kołowy z centrum Pokoju, wyeliminuje uciążliwość komunikacyjną oraz przyczyni się do wyeksponowania historycznego układu urbanistycznego. Zadanie jest wpisane do obowiązującego Planu Zagospodarowania Przestrzennego Województwa Opolskiego.

\section{Literatura}

Adamska M.E., 2017, Rola wartości dziedzictwa kulturowego i środowiska przyrodniczego w lokalnym rozwoju terytorialnym wsi Pokój, [w:] Węcławowicz-Bilska E. (red.), Nowe idee w planowaniu rozwoju terytorialnego, t. 4: Dziedzictwo kulturowe $i$ wartości przyrodnicze w planowaniu przestrzennym. Wybrane przykłady, Wydawnictwo Politechniki Krakowskiej, Kraków: 93-118.

Adamska M.E., 2018, Cmentarze wsi Pokój świadectwem wielokulturowej historii miejscowości/Cemeteries of Pokój as evidence of multicultural history of the village, ,Teka Architektury i Urbanistyki”, 46: 255-270, Oddział PAN w Krakowie.

Bimler K., 1930, Carlsruhe in Oberschlesien, [w:] Die Neuklasische Bauschule in Schlesien, H.2, Breslau.

Chrzanowski T., Kornecki M. (red.), 1968, Katalog zabytków sztuki w Polsce, t. 7: Województwo opolskie, z. 11: Miasto Opole i powiat opolski, Instytut Sztuki PAN, Warszawa: 95-101. 
Chrzanowski T., Kornecki M., 1974, Sztuka Śląska Opolskiego, Wydawnictwo Literackie, Kraków.

Gosławska E. (red.), 2012, Jesteśmy stąd. Gmina Pokój z bliska, 2012, Gminna Biblioteka Publiczna w Pokoju, Pokój.

Gosławska E. (red.), 2015, Pokój. Monografia, Gminna Biblioteka Publiczna w Pokoju, Pokój.

Konwiarz R., 1919, Alt-Schlesien: Architektur. Raumkunst. Kunstgewerbe, Stuttgart.

Nienałtowski M., 2019, Wirtembergowie. Książęta na Oleśnicy, Bierutowie i Dobroszycach 1648-1792, Urdruk, Oleśnica.

Spielvogel I., Migała M., Spałek K., 2012, Opolskie uzdrowiska, Oficyna Wydawnicza Politechniki Opolskiej, Opole: 59-67.

Schmidt J., 1998, Pokój - Carlsruhe (1748-1945). Monografia, Urząd Gminy Pokój, Gminny Ośrodek Kultury w Pokoju, Pokój.

Stumpe F., 1927, Führer durch Bad Carlsruhe O.S. und seine romantische Vergangenheit, Schweidnitz.

Wróbel T., 1971, Zarys historii budowy miast, Zakład Narodowy im. Ossolińskich, Wrocław.

\section{Akty prawne, dokumenty programowe, opracowania}

Gminny Program Opieki nad Zabytkami Gminy Pokój na lata 2016-2019.

Problematyka ochrony dziedzictwa kulturowego i zabytków $w$ studiach uwarunkowań $i$ kierunków zagospodarowania przestrzennego gmin oraz $w$ miejscowych planach zagospodarowania przestrzennego. Poradnik dla planistów i samorzadów lokalnych, 2011, Narodowy Instytut Dziedzictwa, Warszawa.

Rozporządzenie Ministrów: Administracji Publicznej i Ziem Odzyskanych z dnia 12 listopada 1946 roku o przywróceniu i ustaleniu urzędowych nazw miejscowości.

Społeczno-gospodarcze oddziaływanie dziedzictwa kulturowego. Raport z badań społecznych, 2013, Narodowy Instytut Dziedzictwa, Warszawa.

Strategia Ochrony Dziedzictwa Kulturowego Gminy Pokój na lata 2016-2020.

Strategia Rozwoju Gminy Pokój na lata 2014-2020 (Załącznik do uchwały Nr XXXVII/ 323/2014 Rady Gminy Pokój z dnia 7 listopada 2014 roku).

Strategia Rozwoju Obszaru Funkcjonalnego Kluczbork-Namystów-Olesno 2015-2020.

Strategia Rozwoju Województwa Opolskiego do 2020 roku (Załącznik do Uchwały Nr XXV/325/2012 Sejmiku Województwa Opolskiego z dnia 28 grudnia 2012 r.).

Uchwała Nr XVIII/153/2012 Rady Gminy Pokój z dnia 26 listopada 2012 roku w sprawie uchwalenia zmiany Studium uwarunkowań i kierunków zagospodarowania przestrzennego gminy Pokój dla obszaru wsi Pokój.

Uchwała nr XXII/187/2016 Rady Gminy Pokój z dnia 12 października 2016 roku w sprawie zmiany Miejscowego planu zagospodarowania przestrzennego wsi Pokój. 
Ustawa z dnia 23 lipca 2003 roku o ochronie zabytków i opiece nad zabytkami (Dz.U., 2003, nr 162, poz. 1568).

Ustawa z dnia 28 lipca 2005 roku o lecznictwie uzdrowiskowym, uzdrowiskach i obszarach ochrony uzdrowiskowej oraz o gminach uzdrowiskowych (Dz.U., 2005, nr 167, poz. 1399).

Wykaz obiektów zabytkowych nieruchomych wpisanych do rejestru zabytków województwa opolskiego - stan na dzień 15 marca 2020.

\section{Netografia}

http://izbaregionalnapokoj.pl/4/57/historia-izby-regionalnej.html (dostęp: 15.02.2020). http://maps.opolskie.pl/OGIS/default.aspx?gpw=e80bbe29-2a28-4d91-9ace-3c72f0fb8c-

5f (dostęp: 22.07.2020).

http://offilm.pl/ (dostęp: 12.03.2020).

http://www.gminapokoj.pl/1795/2071/film-promocyjny-pokoj-z-widokiem.html (dostęp:

12.03.2020).

http://www.gminapokoj.pl/916/779/festiwal-muzyki-zabytkowych-parkow-i-ogrodow-

-im-carla-marii-webera.html (dostęp: 11.03.2020).

https://fotopolska.eu/1342268,foto.html?o=b13093 (dostęp: 22.04.2020).

https://gminapokoj.pl/ (dostęp: 15.04.2020).

https://gminapokoj.pl/1546/2007/rozbudowa-kanalizacji-sanitarnej-w-pokoju-etap-i.html (dostęp: 15.02.2020).

https:/gminapokoj.pl/1564/2029/iii-stobrawskie-swieto-produktow-lokalnych.html (dostęp: 15.02.2020).

https:/gminapokoj.pl/846/1109/perla-na-stobrawskim-zielonym-szlaku.html (dostęp: 15.02.2020).

https://gminapokoj.pl/3485/2150/zachowanie-dziedzictwa-kulturowego-i-historycznego-poprzez-rewaloryzacje-obiektow-zabytkowych-i-dzialania-edukacyjno-informacyjne-w-wojewodztwie-opolskim.html (dostęp: 15.02.2020).

https://gminapokoj.pl/4028/2196/projekt-pn-nie-bylo-nas-byl-las.html (dostęp: 15.02.2020).

https://gminapokoj.pl/4464/2203/rewaloryzacja-terenow-przyleglych-do-ciekow-w-zabytkowym-parku-w-pokoju.html (dostęp: 15.02.2020).

https://mapadotacji.gov.pl/projekty (dostęp: 15.02.2020).

https://opowiecie.info/dla-wszystkich-jestesmy-lasem-barbara-zajac-wojtem-gminy-po-

koj-rozmawia-leszek-myczka/ (dostęp: 15.03.2020).

https://www.youtube.com/watch?v=XD8wLFqrG-Q (dostęp: 12.03.2020). 


\title{
Cultural heritage of the village of Pokój (former Carlsruhe) in the Opole Province Disappearance, protection, promotion
}

\begin{abstract}
Pokój is a communal village located in the northern part of the Opole Province. In the $18^{\text {th }}$ century Duke Karl Christian Erdmann of Württemberg-Oels erected a residential complex here in the form of a radial composition with a central square, gardens and parks. The place known as Carlsruhe became a cultural and craft center, as well as a recognized health resort since the $19^{\text {th }}$ century. War damage suffered by the village in 1945 interrupted this development. The former Carlsruhe became a village Pokój. This chapter presents activities and projects implemented towards protection and promotion of preserved cultural heritage of Pokój at the background of the place's history and its cultural specificity. The study shows, that after the period of post-war stagnation and degradation, $21^{\text {st }}$ century brings a series of new opportunities and instruments not only for protection of the unique heritage of Pokój and restoration of its former values, but for sustainable use of this heritage for local and regional development as well.
\end{abstract}

Keywords: cultural heritage, actions in the area of protection and promotion, Opole Province, Pokój, Carlsruhe.

Dr hab. inż. arch. Monika Ewa Adamska, Profesor Uczelni

Politechnika Opolska

Wydział Budownictwa i Architektury

Katedra Architektury i Urbanistyki

e-mail: mo.adamska@po.edu.pl

(D) https://orcid.org/0000-0001-7821-3143 